\title{
Gendering Central European History: Changing Representations of Women and Gender in Comparison, 1968-2017
}

\author{
Karen Hagemann and Donna Harsch
}

A jubilee is the perfect time for a critical stocktaking, and this essay uses the occasion of the fiftieth anniversary of Central European History $(C E H)$, the leading American journal of the history of "German-speaking Central Europe," to explore the changing representations of women and gender in this journal since its founding in 1968. ${ }^{1}$ The declared aim of $C E H$ was, according to the founding editor, Douglas A. Unfug, to become a "broadly rather than narrowly defined" journal that covers "all periods from the Middle Ages to the present" and includes, next to "traditional approaches to history," innovative and "experimental methodological approaches."2 As Kenneth F. Ledford, the third CEH editor (after Unfug and Kenneth D. Barkin), wrote in 2005, the journal should simultaneously reflect and drive "the intellectual direction(s) of its eponymous field."3

Women's and gender history is one of the experimental approaches that has driven innovation in the field of Central European history since the 1970s. ${ }^{4}$ This article assesses the degree to which $C E H$ has reflected this intellectual trend. It looks at two main developments in the journal: the representation of female authors and the representation of articles on the subject of women's and gender history. These two indices are related, for, even today, the majority of scholars who work with the approach or on the subject of gender are women-a correlation that also holds true for the gender composition of the authors who published such articles in CEH. Broadly speaking, the percentage of female authors in $C E H$ and of articles on the subject have clearly increased over the last fifty years. This general trend reflects the integration of women into the American history profession as a whole, on the one hand, and the integration of the subdiscipline of women's and gender history into the discipline of history, on the other.

The aim of this essay is to substantiate and offer nuance to the big picture and give it some color and context, and it does so in five steps. First, it provides a brief overview of the integration of women as undergraduate and graduate students and faculty in the discipline of history at US colleges and universities. The percentage of women faculty in the different

\footnotetext{
${ }^{1}$ Douglas A. Unfug, "From the Editor: Notes on Central European Historys" Central European History $(\mathrm{CEH}) 23$, no. 4 (1990): 384. Reprinted in this commemorative issue.

2 "From the Editors" [Douglas A. Unfug], CEH1, no. 1 (1968): 3. Also reprinted in this commemorative issue.

${ }^{3}$ Kenneth F. Ledford, "From the Editors," CEH 38, no. 1 (2005): 1.

${ }^{4}$ See Karen Hagemann and Jean H. Quataert, "Gendering German History: Comparing Historiographies and Academic Cultures in Germany and the U.S. through the Lens of Gender," in Gendering Modern German History: Rewriting Historiography, ed. Karen Hagemann and Jean H. Quataert (Oxford: Berghahn, 2007), $1-38$.
} 
ranks of history departments provides the necessary background for evaluating the degree to which female authors have been integrated into academic history journals. Unfortunately, rank-specific statistics by gender exist mainly for broad categories such as the humanities; they are very sketchy for individual disciplines, including history. No data exist for subfields, including Central European history. Second, the essay briefly discusses the relationship between the integration of women as undergraduate majors, graduate students, and faculty into history departments, and the integration of women's and gender history into the discipline. This information is important for evaluating the level of inclusion of articles on women's and gender history in history journals. Third, it briefly discusses the "peculiarities" of the field of Central European historiography that have influenced the research on women's and gender history in this field - and with it, the approach, as well as the thematic and temporal focus, of publications such as $C E H$.

Next, it analyzes the development of the representation of female authors, i.e., their percentage as authors of "research articles" in CEH for the time period from 1968 to 2017 (contributions to forum debates, review essays, and book reviews are excluded). ${ }^{5}$ For comparison, we conducted a similar analysis of the American Historical Review (AHR) from 1968 to 2017 and the British journal German History (GH) from 1984 to 2017. The juxtaposition with the $A H R$, the leading journal of the US history profession and its parent organization, the American Historical Association (AHA), provides interesting insights into the development of gendered authorship in a journal that features articles on all types of history written (almost exclusively) by historians based in the United States. The British journal GH, which was founded in the fall of 1984, offers a noteworthy comparative case because it, too, is devoted to the history of German-speaking Central Europe. In addition to articles written by scholars based in each journal's respective home country, $C E H$ and $G H$ feature articles submitted by authors from other countries. Of course, neither the $A H R$ nor $G H$ offers a perfect comparison. We nonetheless believe that each provides the reader with necessary context for evaluating the results for $C E H$.

Finally, the essay explores the representation of articles on women's and gender history in $\mathrm{CEH}$ and $\mathrm{GH}$, and the gender composition of their authors. To make this task manageable, it bases the analysis on article titles, counting as articles with a "gendered approach and theme" all publications that included the terms woman/female, gender, men/masculinity, sexuality, and/ or family/marriage/children in the title. Based on this data — which can, admittedly at best, give only a rough indication of general trends-we tabulated how many such articles appeared, tried to identify the changing importance of major subfields of women's and gender history in the two journals, and analyzed which time periods in Central European history were at the focus of the articles with a gendered approach and theme. It would have been very interesting to compare the percentage of manuscripts on women's and gender history submitted to the three journals with the percentage of articles they published, but this is a subject that needs more research.

\section{Women as Students and Teachers of History at US Colleges and Universities}

From the late 1960s onward, women flocked to American colleges and universities for undergraduate and graduate study, encouraged by the rising new women's movement and

\footnotetext{
${ }^{5}$ We counted as "research articles" the contributions that appeared in the article section of the journal. We excluded contributions that appeared in forum discussions, conference reports, review essays, and review sections of the journals.
} 
its demand for equal access to higher education. In the discipline of history, the percentage of female graduate students reached 11 percent in 1969. The proportion of women with full professorships was 6 percent that year. These first female history professors often worked in fields seen as "marginal," such as ancient and medieval history, non-US history, or developing fields such as early modern or social history. ${ }^{6}$

With the increasing number and percentage of female history students, the number and proportion of female PhDs in history also expanded. The percentage of female students of all students who earned a BA in history increased from 36 percent in 1980 to 41 percent in 2012; it has stagnated since then. The percentage of women of all history PhDs increased from 25 percent in 1982 to 45 percent in 2012. These data indicate that there is no longer a "leaky pipeline" in the transition from undergraduate to graduate education in history at American colleges and universities; in fact, the percentage of female graduate students in history is higher than the percentage of female students with a BA in history. ${ }^{7}$

The situation is quite different, however, when one looks at the next step in the academic career: a tenure-track or tenured faculty position in a history department at US colleges or universities. The number of history departments and the number of their fulltime teaching staff (in all types of positions) increased considerably in the last four decades. In 1980, there were 6,469 fulltime teaching staff members in 330 history departments; 906 (14 percent) of them were women). In 2003/2005, there were 15,487 fulltime teaching staff members in 671 history departments; 4,646 (30 percent) of them were women. ${ }^{8}$ The increase of female fulltime teaching faculty in history departments was not only much lower than in the humanities in general, but also remarkably lower than the average of all fields. In 2007, the percentage of female fulltime faculty in history reached 35 percent, but, in the humanities in general, women held 51 percent of fulltime faculty positions - and more than 42 percent of these positions in all academic fields combined (Table 1). ${ }^{9}$ There was, though, some progress over the next five years: the most recent data of the American Academy of Arts and Science show that, by 2012, the proportion of women among all faculty ranks in history departments rose to 39 percent, while staying at 50 percent in the humanities in general. ${ }^{10}$

The positive general trend within the history profession toward a more equal integration of women needs to be differentiated according to rank, however: the higher the position, the smaller the percentage of women. Unfortunately, statistics that differentiate between men and women at each faculty rank in US history departments are only available for 1992 and 2003. In this time period, the percentage of women among assistant professors in history fell from 44 to 33 percent, whereas the percentage of women among associate professors

\footnotetext{
${ }^{6}$ For a recent overview, see Karen Hagemann and Sarah Summers, "Gender and Academic Culture: Women in the Historical Profession of Germany and the United States since 1945," in Modern Germany in Transatlantic Perspective, ed. Michael Meng and Adam R. Seipp (New York: Berghahn, 2017), 100-3.

${ }^{7}$ Ibid.

${ }^{8}$ Ibid., 100.

${ }^{9}$ Robert B. Townsend, "What the Data Reveals about Women Historians," Perspectives on History, May 2010 (https://www.historians.org/publications-and-directories/perspectives-on-history/may-2010/whatthe-data-reveals-about-women-historians).

${ }^{10}$ See "Percentage of Humanities Faculty Members Who Are Women, by Discipline, Fall 2012," Humanities Indicators: A Project by the American Academy of Arts \& Sciences (https://www.humanitiesindicators.org/ content/indicatordoc.aspx?i=483).
} 
Table 1. The Development of the Proportion of Female Faculty in History, in the Humanities, and in All Fields, 1980-2007

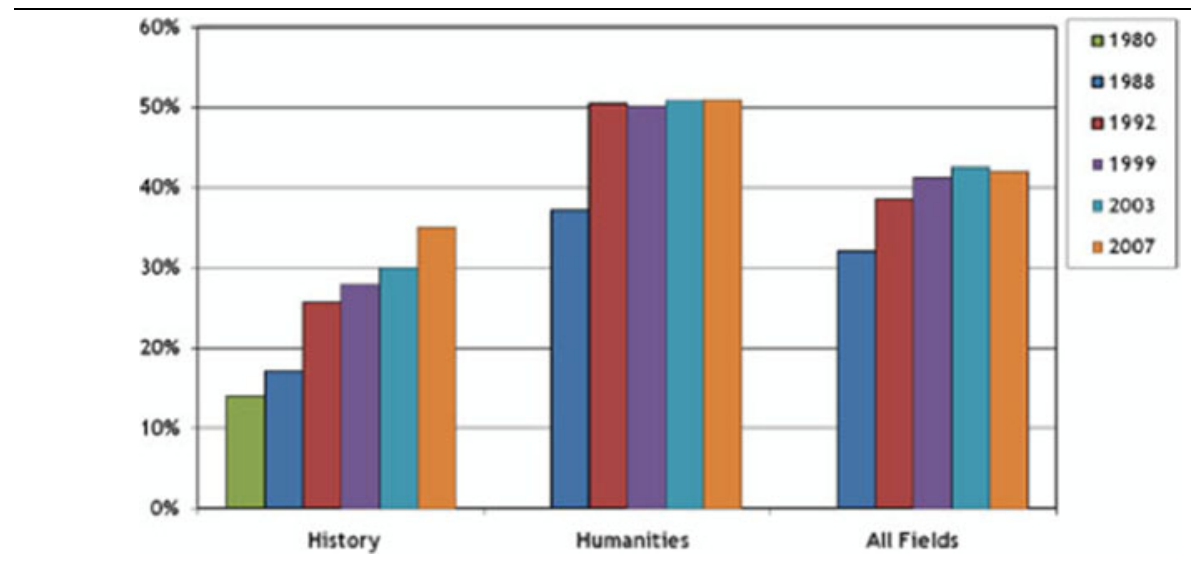

Source: Robert B. Townsend, "What the Data Reveals about Women Historians," Perspectives on History, May 2010 (https://www.historians.org/publications-and-directories/perspectives-on-history/may-2010/ what-the-data-reveals-about-women-historians).

increased from 24 to 26 percent, and among full professors from 12 to 17 percent. ${ }^{11}$ According to the most recent data of the American Academy of Arts and Science for 2012, women made up 51 percent of the assistant professors, and 35 percent of all associate and full professors of the fulltime history faculty. ${ }^{12}$ The data indicate that there is also no longer a "leaky pipeline" for women between graduate school degree and entry into a tenure-track faculty position in history. The percentage of female assistant professors is higher than the proportion of female PhDs in history today. Mainly in the tenured higher ranks of the history profession-associate, fulltime, and especially distinguished professors - women still have not reached equality; the "pipeline" between the rank of assistant professors and higher tenured ranks is still "leaky" in most history departments. ${ }^{13}$

\section{The Rise of Women's and Gender History at US Colleges and Universities}

As they aimed to increase the percentage of women at all levels of higher education, women active in the new women's movement also stood at the vanguard of the development of women's history since the late 1960s. They sought to transform the approach and content of mainstream historical study from history into herstory. For several reasons, women's history emerged as a field earlier in the United States than in other Western countries. ${ }^{14}$

\footnotetext{
${ }^{11}$ Hagemann and Summers, "Gender and Academic Culture," 100.

${ }^{12}$ See "Percentage of Humanities Faculty Members"; as well as Susan White et al., "The 2012-13 Survey of Humanities Departments: Representation of Women among Faculty, Fall 2012," in The 2012-13 Survey of Humanities Departments at Four-Year Institutions (College Park, MD: Statistical Research Center, American Institute of Physics, 2014), 10.

${ }^{13}$ See Hagemann and Summers, "Gender and Academic Culture."

${ }^{14}$ For an international comparison, see Karen Hagemann and María Teresa Fernández-Aceves, eds., "Gendering Trans/National Historiographies: Similarities and Differences in Comparison," Journal of
} 
Especially significant factors were the century-long tradition of women's colleges with female faculty and the early organization of female historians in the United States. Since 1936, the Berkshire Conference of Women Historians has existed as an advocacy organization. The triennial "Big Berks" introduced in 1973 - the major national and international conference on women's and gender history-has greatly expanded its influence. ${ }^{15}$ Furthermore, American women historians founded the Coordinating Council for Women in History $(\mathrm{CCWH})$ in 1969. Its declared aim was and is "to educate men and women on the status of women in the historical profession and to promote research and interpretation in areas of women's history." 16 CCWH stood behind the establishment of a Standing Committee on Women Historians within the AHA and the adoption in 1971 of an extensive AHA program of action for the advancement of women. ${ }^{17} \mathrm{~A}$ further important factor that promoted the greater integration of women into the discipline in the United States was the market dependency of higher education: because colleges and universities depend at least partly on the tuition and fees students have to pay for their education, they were relatively responsive to the wishes and demands of the rising number of female students. As a result, from the 1970s to 1990s, they were more open to the hiring of female professors and to the introduction and expansion of courses first in women's history and later in gender history. ${ }^{18}$ As a result of the interplay of these factors, the percentage of positions at US universities and colleges in the field of women's and gender studies, including history, has increased significantly since the 1970s. Women's and gender history is one of the eleven specializations within the discipline that has grown the most in American history departments over the last four decades. ${ }^{19}$

Since the 1970s, the methods and theoretical framework of women's history have evolved, too. Women's history began as a field in social history, which included demographic history, labor history, family history, and the history of everyday life. In the 1980s, historians of women played a major role in the paradigmatic shift from social history toward discourse analysis and cultural history. This methodological move was related to the transition from women's history to gender history. The linguistic and cultural turns opened the door to the history of sexuality and, since the early 1990s, to the history of masculinity. Fostered by the trend toward postcolonial studies and the "imperial turn," race and ethnicity also became important categories of a gendered analysis of history. Most recently, the growth of transnational and global history has influenced the field of women's and gender history.

Women's History 18, no. 1 (2007): 51-213; on the United States, see Alice Kessler-Harris, "A Rich and Adventurous Journey: The Transnational Journey of Gender History in the United States," in ibid., 153-59; on Britain, see Susan R. Grayzel, "Same Language, Different Academic Cultures: Working Across the Trans-Atlantic Divide," in ibid., 187-92.

15 “History," Berkshire Conference of Women Historians (https://berksconference.org/about/history/).

16 “About the CCWH," Coordinating Council for Women (https://theccwh.org/about-the-ccwh/).

${ }^{17}$ See the following AHA reports: "Committee on Gender Equity" (https://www.historians.org/aboutaha-and-membership/governance/committees/committee-on-gender-equity); "Committee on Women Historians' 1980 Summary Report” (https://www.historians.org/about-aha-and-membership/aha-historyand-archives/historical-archives/ committee-on-women-historians-1980-summary-report).

${ }^{18}$ See Hagemann and Quataert, "Gendering German History”; Hagemann and Summers, "Gender and Academic Culture."

${ }^{19}$ Robert B. Townsend, "The Rise and Decline of History Specializations over the Past 40 Years," Perspectives on History, Dec. 2015 (https://www.historians.org/publications-and-directories/perspectiveson-history/december-2015/the-rise-and-decline-of-history-specializations-over-the-past-40-years). 
Its practitioners started to work on colonialism, imperialism, anticolonial movements, and migration as well. The expansion, diversification, and maturation of the historiography on women and gender is reflected in the evolving content of articles published on gendered approaches and themes in history journals like CEH or GH. ${ }^{20}$

\section{The "Peculiarities" of Central European Historiography}

The gendered composition of the historical profession and the gendered content of historical scholarship have, then, substantially affected the representation in $C E H$ and $G H$ of female authors and of articles on women's and gender history. In addition, the "peculiarities" of the field's historiography have informed not only the representation of women authors and gender themes but also the regional, thematic, and temporal focus of the scholarship. Factors at work here include the specific historiographical tradition of the field of Central European history; changing research interests, which depend on contemporary political developments; as well as the academic culture and fashions in the discipline in general, and in the field of Central European history in particular. ${ }^{21}$

One important "particularity" of the field of Central European history is its long-lasting spatial limitation to German-speaking Central Europe in the historiography, which, for decades, neglected the region of the Habsburg Empire, including Austria. The regional focus of historical research was on Germany proper, and especially on Prussia, with scholars following the tradition of the Borussian historians of the German Empire, who fostered in their master narratives the creation of a kleindeutsche vision of the German nation that excluded Austria. ${ }^{22}$ Only in the last decade, scholarship on the Habsburg Empire has emerged as one of the most innovative fields of Central European history. ${ }^{23}$ The research in women's and gender history reflects this limited regional focus.

Another particularity, according to Konrad H. Jarausch, was that American historians of Germany turned to social-historical methods and perspectives later than their fellow US historians of other regions did. ${ }^{24}$ Because of the importance of the subject of the Third Reich and the attempt to explain the rise of National Socialism, research by historians of Germany remained more focused, into the 1970s and 1980s, on themes of political history. The same holds true for British historians of German history. When American historians of Germany

\footnotetext{
${ }^{20}$ For an introductory overview, see Sonya O. Rose, What is Gender History? (Cambridge: Polity Press, 2010); Laura Lee Downs, Writing Gender History (London: Bloomsbury, 2010). On current debates, see "AHR Forum: Revisiting 'Gender: A Useful Category of Historical Analysis," American Historical Review $(A H R)$ 113, no. 5 (2008): 1344-1429; Cornelia H. Dayton and Lisa Levenstein, "The Big Tent of U.S. Women's and Gender History: A State of the Field," Journal of American History 99, no. 3 (2012): 793-817; Birgitte Söland and Mary Jo Maynes, eds., “The Past and Present of European Women's and Gender History: A Transatlantic Conversation,” Journal of Women's History 25, no. 4 (2013): 288-308.

${ }^{21}$ For the following discussion, also see Catherine Epstein, "German Historians at the Back of the Pack: Hiring Patterns in Modern European History,1945-2010," CEH 46, no. 3 (2013): 599-639; Andrew I. Port, "Central European History since 1989: Historiographical Trends and Post-Wende 'Turns," CEH 48, no. 2 (2015), esp. 238-239.

${ }^{22}$ See Karen Hagemann, Revisiting Prussia's Wars against Napoleon: History, Culture, Memory (Cambridge: Cambridge University Press, 2015), 273-300.

${ }^{23}$ See the forum "A Imperial Dynamo? CEH Forum on Pieter Judson's The Habsburg Empire: A New History," CEH 50, no. 2 (2017): 236-59.

${ }^{24}$ Konrad H. Jarausch, "German Social History: American Style,” Journal of Social History 19, no. 2 (1985): 349-59.
} 
did turn to social history, Jarausch observed, they turned to an "American" version, one that included the histories of women, people of color, and various immigrant communities. Furthermore, as suggested by contributions to the 1989 special issue of CEH on "German Histories: Challenges in Theory, Practice, Technique," US-based historians of Germany made the linguistic and cultural turns later than other fields of history in the United States. This meant that the move from women's to gender history, which was informed by these turns, gained later influence in the field. ${ }^{25}$

In addition, dramatic historical events like the fall of the Berlin Wall in November 1989 and the subsequent unification of the Federal Republic of Germany (FRG) and the German Democratic Republic (GDR) informed work on the field of Central European history in general and, with it, work in women's and gender history. These events, in addition to the almost unlimited access to the archives of former East Germany, moved research interests to post-1945 history. The opening of the archives in Eastern Europe after the collapse of the Soviet Union and other communist states also inspired a new wave of research on the Holocaust and on German occupation in the East during World War II. The "vanishing point" of twentieth-century German history moved further away from 1933 to 1941, a trend that had already started in the 1980s. ${ }^{26}$ These developments clearly influenced as well both the research of women's and gender historians working in the field and the focus of their publications in $C E H$.

\section{The Representation of Female Authors}

The development of the percentage of articles by female authors in the journals $C E H, G H$, and the $A H R$ reflects the trend of the slow integration of women into the historical profession (Table 2). The percentage of women among all authors was very low in the early years of $C E H$, accelerating only slowly and fitfully over the decades. It averaged 9 percent in the 1970s, 13 percent in the 1980s, and 22 percent in the 1990s. In the first decade after the millennium, it increased to 31 percent and has remained at an average of 30 percent since 2010. The parallel figures in GHwere 41 percent in the 1980s, 17 percent in the 1990s, 26 percent in the first decade after the millennium, and 29 percent since 2010 . The two journals look remarkably similar in terms of the gender of authorship since the 1990s. The unusually high proportion in GH in the 1980s was the result of two special issues on themes dealing with women's and gender history; each only had female authors. Despite comparatively low early figures for the $A H R$ in the 1970s and 1980s, that journal has greatly outperformed $C E H$ and $G H$ since the 1990 s in publishing work by female historians. In the $A H R$, female authors wrote, on average, 8 percent of all articles published in the 1970s, and 7 percent in the 1980s, but that share increased sharply to 37 percent in the 1990s; it stagnated at 36 percent in the first decade after the millennium, and has grown to 41 percent since 2010 , which is higher than the average proportion of women among all fulltime history faculty.

\footnotetext{
${ }^{25}$ See the special issue "German Histories: Challenges in Theory, Practice, Technique," CEH 22, no. 3-4 (1989): 229-457, esp. Jane Caplan, "Postmodernism, Poststructuralism, and Deconstruction: Notes for Historians," and Isabel V. Hull, "Feminist and Gender History through the Literary Looking Glass: German Historiography in Postmodern Times," in ibid., 260-78, 279-300.

${ }^{26}$ Helmut Walser Smith, “The Vanishing Point of German History: An Essay on Perspective," History \& Memory 17, nos. 1/2 (2005): 269-95.
} 
Table 2. The Percentage of Female Authors of Research Articles of All Authors in CEH, German History, and the AHR, 1968-2017

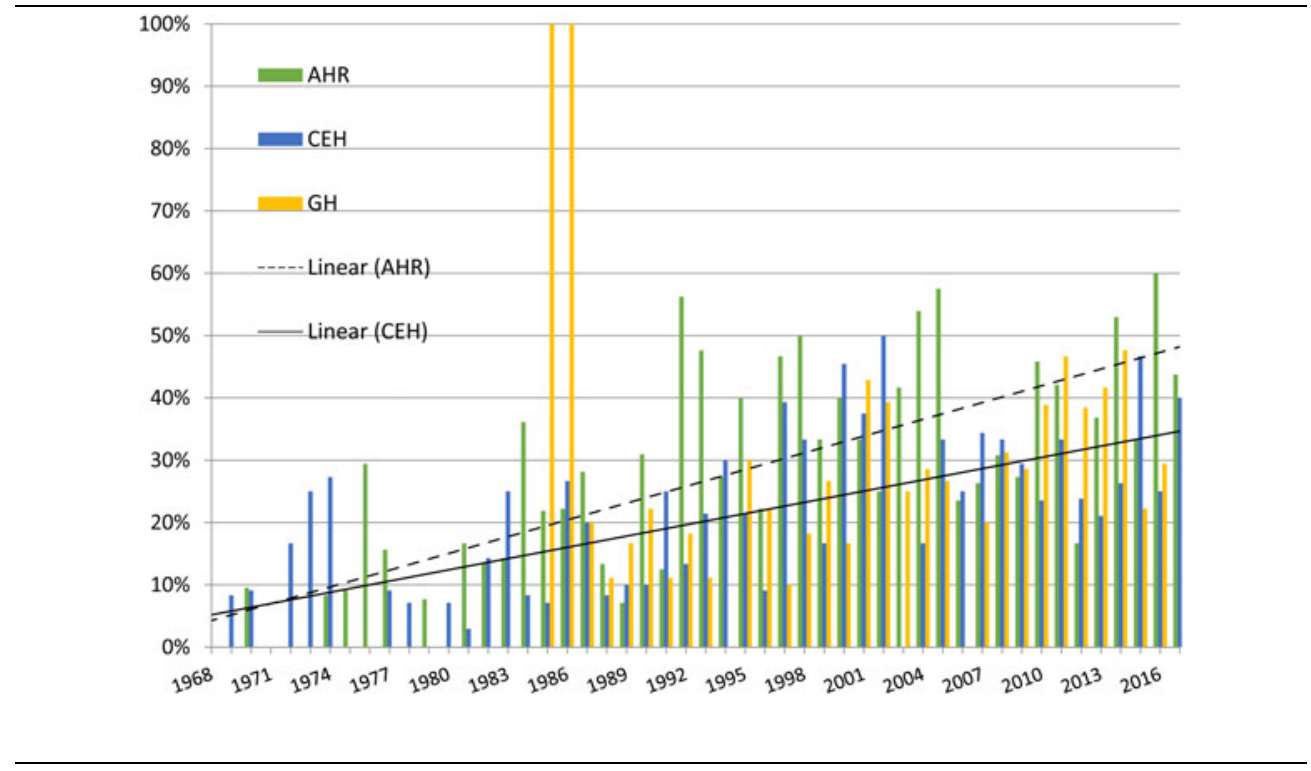

Table 2 indicates a gradually rising slope, with up-and-down bounces. Peak years were followed by troughs, during which all three journals published volumes that included no or only one article by a female author. Still, across five decades, there was clearly a rising trend in the representation of women authors, reflecting the integration of women into the history profession more generally. When CEH began publication in 1968, the percentage of women faculty in history in the United States was, as we have seen, extremely low. This did not change much in the 1970s. It is unsurprising that the percentage of all articles written by women featured in the journal remained small that decade, similar to the AHR. In the 1980s, as the proportion of women among historians at US universities inched upward, so, too, did the rate of publication of women's scholarship in CEH and the $A H R$ - but still only very slowly. Women fared much better in all three journals in the 1990s, which reflected the increasing integration of women into the profession. Yet, compared to the $A H R$, which became and remains the vanguard in the relatively representation of female authors, $C E H$ and $G H$ were laggards. The representation of women among all authors in CEH during the 1990s fell short of the increased number of women historians working in history departments in the United States. Only since the millennium has the percentage of women's scholarship in CEH caught up, if barely, to the average gender composition of fulltime history faculty in all fields and regions of study. In comparison, the representation of women's scholarship in the AHR has been slightly higher than their representation among faculty in the discipline over the last decade. Two reasons for this might be the profusion of scholarship on women and gender in US history over the last three decades - still the largest regional field in the discipline - and the gender policy of the $A H R$, which actively supports the inclusion of female authors and subjects related to women's and gender history. 


\section{The Representation of Articles on Women's and Gender History}

The rise in the percentage of female authors and the increase of the proportion of women's and gender history articles in $C E H, G H$, and $A H R$ are clearly related. Most authors of articles with a gendered approach or theme were and still are women (Tables 4 and 5). But because only a relatively small proportion of all female historians works on women's and gender history, the rise in the proportion of articles on women's and gender history was, on average, lower than the rise in female authorship. According to a 2015 review essay by current CEH editor Andrew I. Port, "Central European History since 1989: Historiographical Trends and Post-Wende 'Turns,", only 3.5 percent of all articles in CEH focused on themes related to "gender, women, family" between 1968 and 1987. This proportion increased to 12.6 percent between 1990 and 2014. ${ }^{27}$ Our analysis confirms this trend, but, as Table 3 indicates, the ratio of articles with a gendered approach or theme has fluctuated without a clear trend, similar to the proportion of women authors. On average, 11 percent of all research articles published in CEH between 1968 and 2017, and 14 percent published in GH between 1984 and 2017, focused on a gendered approach or theme. In 2017, 10 percent of all articles in $C E H$ and 17 percent in GH were related to women's and gender history, broadly defined.

Central European History published its first article on the subject of women's history five years after its founding in 1968. ${ }^{28}$ "Beyond Kinder, Küche, Kirche: Weimar Women at Work" by Renate Bridenthal, which appeared in 1973, reflected the thematic and temporal focus of the work by the first generation of American women's historians who studied German history; many of them investigated women in Weimar and Nazi Germany. ${ }^{29} \mathrm{Up}$ to 1980 , this remained the only article on a theme from the evolving field of women's history. During the 1980s, 7 percent of all research articles had a gendered approach or theme in CEH. In the 1990s, the share increased to 12 percent and stayed at this level in the first decade after the millennium. After 2010, it further increased to 17 percent. As the data in Table 3 indicate, the proportion of articles on women's and gender history among all research articles published in $C E H$ has grown slowly but steadily.

A similar trend in content can be seen in German History, which was founded 1984, nearly two decades after CEH. By the mid-1980s, women's history was a recognized, if still nascent, field. Accordingly, GH started very strongly: in its first five years, 18 percent of all published research articles focused, on average, on women's and gender history. The first article on women's history was published in 1985 by Lyndal Roper: "Housework and Livelihood: Towards the 'Alltagsgeschichte' of Women." 30 This strong presence of women's history in those first years did not, however, presage a main role in the journal in later years. In the 1990s, the average fell to 11 percent, and, in the following two decades, the percentage

\footnotetext{
${ }^{27}$ See Port, "Central European History," 245.

${ }^{28}$ Renate Bridenthal, "Beyond Kinder, Küche, Kirche: Weimar Women at Work," CEH 6, no. 2 (1973): 148-66.

${ }^{29}$ For one of the first publications on German women's history, see Renate Bridenthal et al., eds., When Biology Became Destiny: Women in Weimar and Nazi Germany (New York: Monthly Review Press, 1984); for an overview of the development of international research in the field of women's and gender history (and its subfields) in modern German history, see Hagemann and Quataert, Gendering Modern German History.

${ }^{30}$ Lyndal Roper, "Housework and Livelihood: Towards the Alltagsgeschichte of Women,"

German History (GH) 1 no. 2 (1985): 3-9.
} 
Table 3. Percentage of Research Articles on Women's and Gender History of all Articles in CEH (1968-2017) and German History (1984-2017)

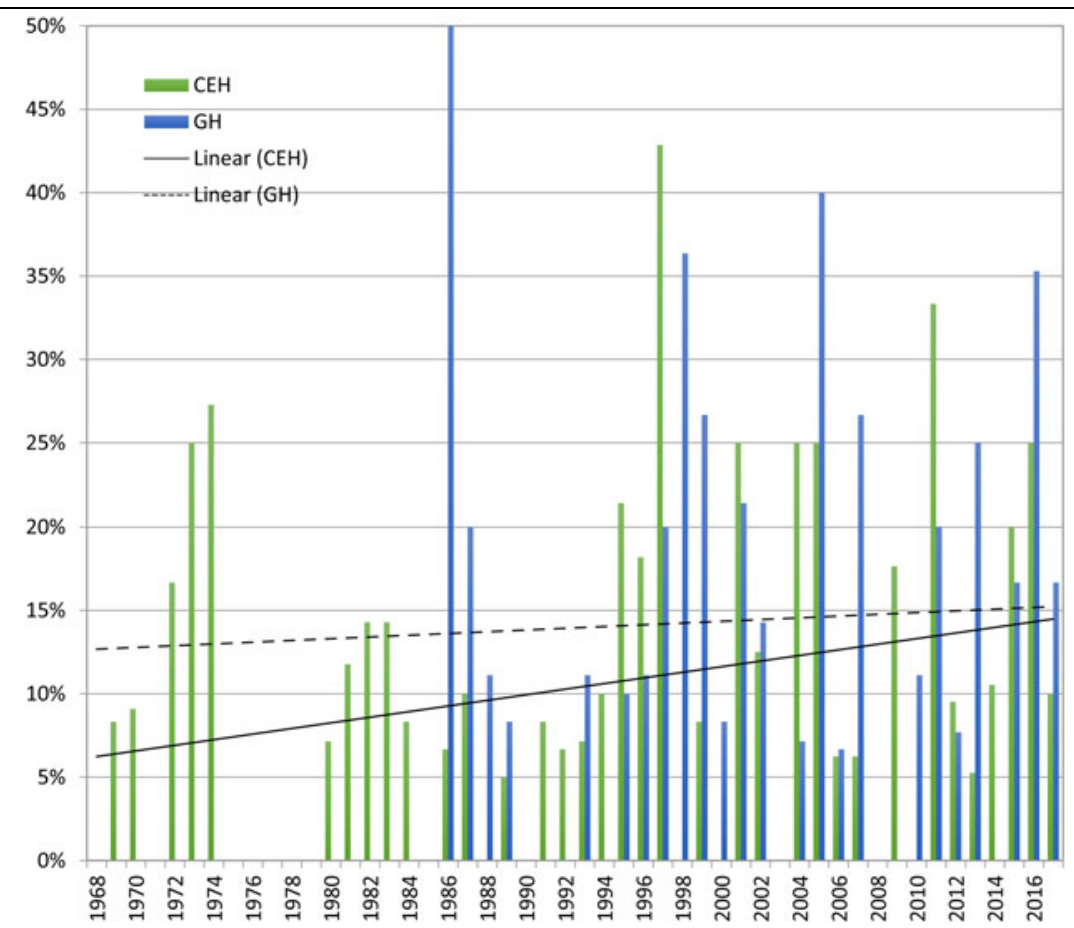

increased again — similar to $\mathrm{CEH}$ - to 14 percent in the first decade after the millennium, and to 17 percent since 2010 (Table 3).

In both journals, the regional focus of articles on women's and gender history was and is, for the nineteenth and twentieth centuries, on Kleindeutschland and especially on Prussia (until its dissolution in 1945). Articles that focus on women and gender in the Habsburg Empire and the regions it encompassed, are-like articles on those regions in the journals more generally - still rare, despite repeated attempts by the editors to encourage more submissions in these areas, and despite a recent increase in research on these regions. ${ }^{31}$

An analysis of temporal coverage (Table 4) shows that, of all seventy-five articles with a gendered approach or theme published in Central European History between 1968 and 2017, 28 percent focused on the "long" nineteenth century, 20 percent each on the Weimar Republic and post-1945 period, and 12 percent on Nazi Germany, World War II, or the Holocaust. It is remarkable that, on average, the nineteenth century was-followed by Weimar Germany - the period studied most by research articles on women's and gender history published in CEH between 1968 and 2017, reflecting the general importance of

${ }^{31}$ See Kenneth D. Barkin, "Thoughts on Thirteen Years of Editing CEH," CEH 37, no. 4 (2004): 499-500 [reprinted in this commemorative issue]; Ledford, "From the Editors," 2. 
Table 4. Number and Percentage of Research Articles by Male and Female Authors on Women's and Gender History by Time Period in CEH (1968-2017) and German History (1984-2017)

\begin{tabular}{|c|c|c|c|c|c|c|c|c|c|}
\hline Time Period & & Until 1800 & 1800-1914 & 1914-1918 & 1919-1933 & 1933-1945 & 5Ince 1945 & Theory & Total \\
\hline \multirow[t]{6}{*}{ CEH } & \multirow[t]{2}{*}{ Women } & 3 & 13 & 4 & 11 & 9 & 13 & 4 & 57 \\
\hline & & $5.3 \%$ & $22.8 \%$ & $7.0 \%$ & $19.3 \%$ & $15.8 \%$ & $22.8 \%$ & $7.0 \%$ & $100.0 \%$ \\
\hline & \multirow[t]{2}{*}{ Men } & 3 & 8 & 0 & 4 & 0 & 2 & 1 & 18 \\
\hline & & $16.7 \%$ & $44.4 \%$ & $0.0 \%$ & $22.2 \%$ & $0.0 \%$ & $11.1 \%$ & $5.6 \%$ & $100.0 \%$ \\
\hline & \multirow[t]{2}{*}{ Total } & 6 & 21 & 4 & 15 & 9 & 15 & 5 & 75 \\
\hline & & $8.0 \%$ & $28.0 \%$ & $5.3 \%$ & $20.0 \%$ & $12.0 \%$ & $20.0 \%$ & $6.7 \%$ & $100.0 \%$ \\
\hline \multirow[t]{6}{*}{ GH } & \multirow[t]{2}{*}{ Women } & 8 & 10 & 1 & 4 & 12 & 8 & 1 & 44 \\
\hline & & $18.2 \%$ & $22.7 \%$ & $2.3 \%$ & $9.1 \%$ & $27.3 \%$ & $18.2 \%$ & $2.3 \%$ & $100.0 \%$ \\
\hline & \multirow[t]{2}{*}{ Men } & 5 & 5 & 0 & 3 & 5 & 5 & 2 & 25 \\
\hline & & $20.0 \%$ & $20.0 \%$ & $0.0 \%$ & $12.0 \%$ & $20.0 \%$ & $20.0 \%$ & $8.0 \%$ & 1 \\
\hline & \multirow[t]{2}{*}{ Total } & 13 & 15 & 1 & 7 & 17 & 13 & 3 & 69 \\
\hline & & $18.8 \%$ & $21.7 \%$ & $1.4 \%$ & $10.1 \%$ & $24.6 \%$ & $18.8 \%$ & $4.3 \%$ & $100.0 \%$ \\
\hline
\end{tabular}


Table 5. Number and Percentage of Research Articles by Male and Female Authors on Women's and Gender History by Approaches in CEH (1968-2017) and German History (1984-2017)

\begin{tabular}{cccccccc}
\hline & & $\begin{array}{c}\text { Women's } \\
\text { History }\end{array}$ & $\begin{array}{c}\text { Gender } \\
\text { History }\end{array}$ & $\begin{array}{c}\text { History of } \\
\text { Sexuality }\end{array}$ & $\begin{array}{c}\text { History of } \\
\text { Masculinity }\end{array}$ & $\begin{array}{c}\text { History of } \\
\text { the Family }\end{array}$ & Total \\
\hline CEH & Women & 10 & 28 & 7 & 5 & 7 & 57 \\
& & $17.5 \%$ & $49.1 \%$ & $12.3 \%$ & $8.8 \%$ & $12.3 \%$ & $100.0 \%$ \\
& Men & 8 & 1 & 7 & 1 & 1 & 18 \\
& & $44.4 \%$ & $5.6 \%$ & $38.9 \%$ & $5.6 \%$ & $5.6 \%$ & $100.0 \%$ \\
& Total & 18 & 29 & 14 & 6 & 8 & 75 \\
& & $24.0 \%$ & $38.7 \%$ & $18.7 \%$ & $8.0 \%$ & $10.7 \%$ & $100.0 \%$ \\
GH & Women & 13 & 16 & 5 & 2 & 8 & 44 \\
& & $29.5 \%$ & $36.4 \%$ & $11.4 \%$ & $4.5 \%$ & $18.2 \%$ & $100.0 \%$ \\
& \multirow{2}{*}{ Men } & 7 & 6 & 6 & 2 & 4 & 25 \\
& & $28.0 \%$ & $24.0 \%$ & $24.0 \%$ & $8.0 \%$ & $16.0 \%$ & $100.0 \%$ \\
& Total & 20 & 22 & 11 & 4 & 12 & 69 \\
& $29.0 \%$ & $31.9 \%$ & $15.9 \%$ & $5.8 \%$ & $17.4 \%$ & $100.0 \%$ \\
\hline
\end{tabular}

the nineteenth century for the development of the modern gender order and gender ideology.

A breakdown by decade of publications shows, however, a clear shift in temporal focus toward the twentieth century. In the 1980s, of the eight articles that had a gendered approach or theme, four focused on the nineteenth century, two on questions of historiography, one on the eighteenth century, and one on Nazi Germany. Since the 1990s, however, articles on the twentieth century have always outnumbered those on earlier periods. In the 1990s, the number of articles on a gendered approach or theme reached twenty-one, with eight exploring Weimar Germany, five the nineteenth century, three the early modern period, two post1945 German history, and one Nazi Germany. Of the eighteen articles published in the first decade after the millennium, five focused on the nineteenth century, four each on Weimar Germany and post-1945 history, three on Nazi Germany, two on World War I, and one on questions of historiography. Since 2010, there has been an even more dramatic shift: of the twenty articles on the subject of women's and gender history, nine focused on post-1945 German history, four on Nazi Germany, three each on World War I and Weimar Germany, one each on early modern Germany, on nineteenth-century Germany, and on questions of historiography. Within the studies focusing on twentieth-century history, the pendulum has clearly swung toward post-1945 Germany history. These trends seem to reflect the general development of temporal coverage in the journal, as Andrew I. Port discussed in his 2015 review essay. ${ }^{32}$ The early modern period has never played a major role for articles with a gendered approach and theme in the $C E H$, something which is not the case for the journal more generally: the early modern period has gained more attention since the 1990s, thanks to editorial attempts to strengthen its presence. ${ }^{33}$

In German History the temporal focus of research articles on women's and gender history was clearly different (Table 4). Of the sixty-nine articles published in GH between 1984 and 2017 with a gendered approach or theme, 25 percent focused on Nazi Germany, 22 percent

\footnotetext{
${ }^{32}$ Port, "Central European History," 241.

${ }^{33}$ See ibid., 242, 244; Barkin, "Thoughts," 499.
} 
on the "long" nineteenth century, and 19 percent each on the early modern period and post1945 history. GH distinctly published more gender-themed articles on Nazi Germany and on the early modern period. The recent trend toward post-1945 history is much less developed in the journal. In the 1990s, a total of thirteen gender-themed articles appeared in GH, with five focusing on the early modern period, four on Nazi Germany, two on the "long" nineteenth century, and one each on the Weimar Republic and questions of historiography. Of the eighteen articles published in the following decade, seven focused on the post-1945 period, six on Nazi Germany, three on the nineteenth century, and one each on World War I, Weimar Germany, and questions of historiography. Of the eighteen articles appearing since 2010, five each focused on the nineteenth century and on Nazi Germany, three each on the early modern period and on Weimar Germany, and one each on World War I and the post-1945 period. The dissimilar temporal foci of women's and gender history articles published in $\mathrm{GH}$ reflect different research interests in the field of Central European history in Britain, where the study of early modern history has played a more important role in the field than it has in the US since the 1980s; Nazi Germany is still an important subject as well for historians of women and gender based in the United Kingdom.

The thematic focus and methodological approach of articles on women's and gender history also shifted over the last decades in both journals. This development reflected first and foremost the paradigmatic changes in scholarship on women's and gender history, as well as the factors that influenced the peculiar development of the field of Central European history more generally (both discussed earlier). Of all seventy-five research articles published between 1968 and 2017 on women's and gender history in CEH, 39 percent emphasized a gender history approach in their title, 24 percent women's history, 19 percent the history of sexuality, 11 percent family history, and 8 percent the history of masculinity. Of all sixty-nine research articles on women's and gender history published between 1985 and 2017 in GH, 32 percent emphasized a gender history approach in their title, 29 percent women's history, 17 percent family history, 16 percent the history of sexuality, and 6 percent the history of masculinity (Table 5).

The linguistic and cultural turns informed the shift from a women's and family historyrooted in social history - to gender history, the history of sexuality, and the history of masculinity. It is interesting that, in both journals, the history of sexuality, often in combination with a focus on homosexuality and masculinity, attracted more male than female authors, even though the former represent a minority of the authors of articles published in both journals on gendered approaches and themes: men wrote only 24 percent of all seventyfive articles published in CEH between 1968 and 2017 on the subject of women's and gender history, broadly defined. The trend in GH was somewhat higher: men wrote 36 percent of all sixty-nine articles published between 1984 and 2017 with a gendered approach or theme (Table 5).

\section{Conclusion}

The representation of female authors in Central European History has risen from virtually nil in its first years of publication to an average of 30 percent since 2010. This proportion is 9 percent below the average of female faculty in US history in 2012. CEH has lagged behind the representation of women authors in the AHR since the 1990s, but the gap is narrower today than ever before. Nearly 17 percent of all articles published in the journal since 
2010 were on a theme broadly defined as women's and gender history, reflecting the steady rise of the field in the US history profession and its representation in history departments in the United States. Both are positive trends. Yet, there is still some work to do if we want to reach gender equality in $C E H$. The aim should be that the percentage of female authors reflects at least the percentage of female full-time faculty in history departments. The proportion of articles on the subject of women's and gender history could also increase further. Gender as a methodology should become one self-evident category of historical analysis next to others intersectional categories like class, race, ethnicity, and sexuality for all scholarship.

The trends in CEH and GH look strikingly similar since the late 1990s, both with respect to the representation of women as authors of research articles and the percentage of articles on themes related to women's and gender history. Given the similarity between the two journals, as well as the differences between them and the AHR since the 1990s-something that needs to be explored in more detail—we wonder if there is a transatlantic "German-history effect" in the gendering of authorship and the themes, based on the particularities of the field of Central European history discussed in this essay. ${ }^{34}$ These peculiarities could be one reason for the gap since the 1990s between CEH and GH and the AHR in terms of the representation of female authors and articles on women's and gender history. For more definitive answers, a comparison with (West) German history journals like the Historische Zeitschrift or Geschichte und Gesellschaft would be useful, given the different academic culture in the Federal Republic - especially the slower integration there of women in the historical profession-as well as the more reluctant recognition of women's and gender history as a legitimate field of study by the mainstream in the discipline. ${ }^{35}$ That, however, is a different story-und ein weites Feld ...

University of North Carolina at Chapel Hill Carnegie Mellon University

\footnotetext{
${ }^{34}$ See Jarausch, "German Social History."

${ }^{35}$ For a comparative analysis through the 1990s of Austrian, British, German, and US history journals focusing on women's and gender history, see Dagmar Freist, "Zeitschriften zur historischen Frauenforschung. Ein internationaler Vergleich," Geschichte und Gesellschaft 22, no. 1 (1996): 97-117; on recent developments in Germany, see Karen Hagemann, "Gleichberechtigt? Frauen in der bundesdeutschen Geschichtswissenschaft,” Zeithistorische Forschungen 13, no. 1 (2016): 108-35.
} 